\title{
A VALIDATION OF THE SHORT-TERM INTERNATIONAL TEACHING ASSIGNMENTS SCALE
}

\author{
Juraifa Jais ${ }^{\star}$ \\ Universiti Tenaga Nasional \\ Kosmas Smyrnios \\ RMIT University \\ Lynnel Hoare \\ RMIT University
}

\begin{abstract}
Many researchers highlighted the need to develop organizational guidelines to enable the effective support and maintenance of critical human resources during expatriate sojourns. However, lack of instruments that measure perceived support for fly-in, fly-out academics has been a shortcoming in past research. In this study, the development of the Short-term International Teaching Assignments Scale (STITAS) is described. The STITAS was composed of 13 items aimed to measure four factors of perceived support: organisational support, HR support, financial support and career support. The STITAS was piloted with 193 fly-in, fly-out academics from 24 Australian universities that participated actively in transnational education. Data analyses involved Exploratory Factor Analysis and Confirmatory Factor Analysis. Cronbach's alpha of the STITA was found to be 0.85 , and the construct validity with the fourfactor structure was confirmed with GFI $=0.917$.
\end{abstract}

Keywords: Instrument Development; Academics; Short-Term Assignments; Australia.

\section{INTRODUCTION}

In recent decades, international business has grown rapidly, leading to heightened pressures on organisations to expand operations into the global business arena (Ahsan \& Musteen 2011). Globalisation, together with neo-liberalism have transformed universities from parochial stable organisations into internationally competitive corporations (Marginson 1999), leading to permanently changed local institutions (Marginson 2003). The higher education sector is not an exception to this push. Australian universities are increasingly reliant on income generated through teaching from onshore and offshore students (Naidoo 2009). Neo-liberalism asserts that the market is the core institution of modern-capitalist-societies and that both domestic and international politics are (and should be) increasingly concerned with making markets work well (Cerny 2004, p. 4).

\& Corresponding author: Department of Management \& HR, College of Business Management and Accounting, Universiti Tenaga Nasional, Malaysia. Email: juraifa@uniten.edu.my 
In the globalised neo-liberal age, higher education policies have focused on developing entrepreneurial practices, moulding universities into enterprise-oriented universities (Marginson \& Considine 2000b). A number of authors (Bolton \& Nie 2010; Adam 2001; McBurnie \& Ziguras 2001) concur with the view that higher education is part of a growing globalisation of trade in goods and services. As a result, market mechanisms such as funding grant cuts to encourage Australian universities to create revenue and reduce dependence on federal government funds have been implemented (Meek \& Hayden 2005). In adapting to changes associated with neo-liberalism, funding for Australian universities comes primarily from fee-paying Australian and international students, research activities, and from return on investment of capital assets (Bay 2011). This market approach has indeed helped to promulgate international student intake in Australian universities (Zheng 2010).

International Development Program of Australian Universities and Colleges Ltd (IDP) predicted that the number of international students pursuing education in or from a foreign country will increase to 3.1 million in 2025 (McBurnie \& Ziguras 2001). Naidoo (2006) agreed that the growth in export of education has shifted from aid to trade. According to the IDP (2010), the demand for Australian international higher education will grow from 163,345 in 2005 to 290,848 in 2025 . While much of this teaching occurs at onshore university campuses, there has been a growth in the use of teaching partnerships in Asia, where courses are delivered by Australian-based academics (Ziguras 2007). Table 1 shows the growth in transnational education enrolments between 2004 and 2011, demonstrating an almost three fold increase in international students since 2004 (Australia Education International 2011; Australian Bureau of Statistics 2011; DEEWR 2011; DEST 2011).

Table 1: Students enrolled in transnational education

\begin{tabular}{ccc}
\hline Year & International students (onshore \& offshore) & Offshore students \\
\hline 2004 & 186449 & 51833 \\
2007 & 273099 & 72282 \\
2010 & 470000 & 76446 \\
2011 & 557425 & 80454 \\
\hline
\end{tabular}

Given the changing topography of higher education, transnational education presents a unique opportunity for academic staff to be internationally mobile (Onsman 2010). Since the 1990s, new recruitment policy strategies and the liberalisation of trade policies by successive Australian governments have increased the scale and speed of cross-border academic mobility (Kim 2009a). Hoffman (2009) and Kim (2009b) concur that the international mobility of academics between institutions is an integral approach for developing communication, collaboration and scientific progress.

At present, there is no complete central source of data on fly-in, fly-out academics, which are the backbone of a multi-billion dollar industry. Even though mobile students are well covered by official data (Ziguras \& McBurnie 2008), governments and universities retain little consolidated information about fly-in, fly-out academics. The increasing mobility 
of academics generates a number of important issues (e.g., career, work-life balance). In addition to teaching offshore responsibilities, academics are accountable for onshore teaching, research, supervision, mentoring, and publishing (Leask 2004). Given these varied roles and responsibilities, academics are faced with the challenge of balancing their work and life outside of work.

Despite its significance, studies focusing on the organisational support for fly-in, fly-out academics are almost non-existent (Dunn \& Wallace 2006; Debowski 2003; Gribble \& Ziguras 2003). Furthermore, there is a lack of commonly accepted measurement instrument that comprises all components of support for fly-in, fly-out academics. Thus, this study aims to fill this gap through conceptualising and developing a multidimensional perceived support measurement for short-term international teaching assignments. Drawing on perceived organisational support (POS) literature (Eisenberger et al. 1986), this study extends current conceptualizations of POS and takes a broad spectrum approach to an understanding of support for fly-in, fly-out academics.

\subsection{Perceived Organisational Support}

Eisenberger, Huntington, Hutchison and Sowa (1986, p. 9) introduced the notion of organisational support for employees, proposing the perceptions of organisational support (POS) construct. POS is a measure of employees' general beliefs about the extent to which an organisation values their membership, commitment of them, and concerned about employees' well-being (Eisenberger et al. 1986). The POS concept is derived from organisational support theory and multiple studies on causes and consequences of employee perceptions of support (Erdogan \& Enders 2007; Eisenberger et al. 2002).

According to organisational support theory, POS associated with employees' tendency to anthropomorphise organisations (Edwards 2009). In this regard, POS is enhanced when employees believe that any investment and recognition of their contributions are voluntary rather than as an outcome of external controls such as government rules or union pressures (Rhoades \& Eisenberger 2002; Armeli et al. 1998). High POS occurs when employees' needs for esteem, approval, and social identity are met, reinforcing an expectation that performance outcomes and anticipated behaviors are acknowledged and rewarded (Aselage \& Eisenberger 2003). Such support enhances employees commitment to organisations (Coyle-Shapiro \& Conway 2005). Thus, organisational commitment to employees contributes to fostering POS (Allen, Shore \& Griffeth 2003).

Theoretical and empirical work relating to POS can be traced back to the seminal work of Blau (1964), who proposed a theory of social exchange involving trust and earn trustworthiness as essential components. In social exchange relationships, norms of reciprocity (Gouldner 1960) dictate that perceptions of support from organisations create obligations to repay that organisation for its commitment and care (Allen, Shore \& Griffeth 2003). When relationships conform to norms of reciprocity and when patterns of exchange are perceived as fair, individuals are more likely than not, to believe that they will not be exploited (Blau 1964). Parties involved understand that favors received in the present create expectations of 
repayment in the future (Gouldner 1960). To exemplify, caring actions of a partner generate a sense of indebtedness on the part of the other partner, which can direct to beneficial attitudes and behaviors directed toward the caring partner (Colquitt, Scott \& LePine 2007).

\subsection{The short-term international teaching assignments scale (STITAS)}

However, the existing scale of POS involves limited consideration of support factors for shortterm international teaching assignments. Within this context, the STITAS was developed on the premise that there are certain support needed by fly-in,fly-out academics. The development of the STITAS represents the overarching goal of this research. This study forms part of a large scale project focusing on the impact on careers, wellbeing, and experiences of fly-in, fly-out academics while at home and abroad during the course of undertaking short-term international teaching assignments. The following section describes the present Method including item generation, participants, data collection, statistical procedures, and reports on validity and reliability of STITAS.

\section{METHOD}

\subsection{Item generation}

The initial items included in the STITAS were based on the related literature (Debowski 2003; Gribble \& Ziguras 2003), critical reflections, and semi-structured interviews to explore and confirm sub dimensions of perceived support. Semi-structured interviews were conducted with 11 academics (eight males, three females) identified from the RMIT University website. This university is actively and extensively involved in Australian transnational education, having the highest number of offshore student enrolments (DEEWR 2011).

In terms of teaching experiences, most participants can be classified as either 'moderately' or 'highly experienced' in short-term assignments, having taught predominantly in Singapore and China, also having teaching experiences in Malaysia, Hong Kong and Vietnam. Participants' level of appointment include Academic Directors $(n=2)$, Senior Lecturers $(n=4)$, and Level B Lecturer $(n=5)$, the academics of which have taught into offshore degree programs. Transcripts were read and analysed using open coding until patterns of groups and themes emerged (Creswell 2007). Continuous comparisons were made between codes created and data gathered in order to generate categories and to verify relationships. Three major themes are identified: perceived organisational HR support, perceived organisational financial support, and perceived organisational career support. Details of this stage are described elsewhere (Jais 2012).

The next step in the development of the measure involved generating 19-item scales related to the dimensions of perceived organisational support (perceived organisational HR support, perceived organisational financial support, and perceived organisational career support). Consistent with Kraimer and Wayne (2004), Eisenberger et al. (1986), and Shore and Tetrick (1991), content validity of the scale was determined by administering it to 30 academics and 11 doctoral students. Participants received a copy of the 19-item draft instrument and operational definitions for the three dimensions identified in the qualitative study. All constructs are measured on 5-point Likert scales ranging from Strongly Disagree to Strongly Agree. They 
were also requested to rate both the relevance and clarity of each item on two dimensions, each using a scale of 1 to 4 . For relevance, a rating of 1 meant not relevant and 4 indicated highly relevant; for clarity, a rating of 1 meant very confusing and 4 indicated an item was very clear. Items not assigned to a dimension were deleted. This process resulted in an 18-item scale. Eighteen items plus the original 8 items from the POS scale were subjected to an exploratory factor analysis (EFA), the findings of which are detailed in the Results.

\subsection{Participants}

Participants are 193 fly-in, fly-out academics from 24 Australian universities. These universities were selected because they are known to be active in transnational education from their websites and/or their Australian Universities Quality Agency (AUQA) reports (IDP 2009; AVCC 2001). The recruitment pool consisted of academics from a spectrum of disciplinary areas (Education, Engineering, Business, Information Technology, Law, Arts, Health, Humanities and Science) and experienced in transnational teaching. Table 2 shows selected universities arranged into six groups on the bases of institutional type. The recruitment pool consisted of academics from a spectrum of disciplinary areas (Education, Engineering, Business, Information Technology, Law, Arts, Health, Humanities and Science) and experienced in transnational teaching.

Table 2: Classification of university association

\begin{tabular}{ll}
\hline \multicolumn{1}{c}{ Segment } & \multicolumn{1}{c}{ Selected Universities } \\
\hline Sandstones & University of Western Australia \\
Redbricks & Australian National University University of New South Wales \\
& Monash University \\
Unitechs & RMIT University \\
& Queensland University of Technology \\
& Curtin University \\
& University of South Australia \\
Gumtrees & Griffith University \\
& James Cook University \\
& Flinders University \\
& Deakin University \\
& Macquarie University \\
& Murdoch University \\
& University of New England \\
& Central Queensland University \\
& Edith Cowan University \\
Charles Sturt University \\
Private & Victoria University of Technology Swinburne University of Technology University \\
& of Ballarat \\
& University of Canberra \\
& Charles Darwin University \\
& Bond University \\
\hline
\end{tabular}

Note: Adapted from Marginson and Considine (2000a, p. 190). 
Owing to the unavailability of a commercially available fly-in, fly-out academics database, sample of prospective participants was obtained by retrieving a list of academics from official universities websites. A snowballing sampling procedure was adopted, whereby participants referred the researcher to other potential informants. A snowball sample emerged during the e-mailed surveys. Participant demographics reveals the typical participant is aged 50 years or older $(48.3 \%)$, male $(65.3 \%)$, living as part of a family with children $(39.9 \%)$, working more than 40 hours each week $(46 \%)$, and holding more than 5 years $(58.5 \%)$ tenure. The majority of participants are lecturers $(31 \%)$, holding continuing full-time employment status $(68.4 \%)$, with more than 5 years of offshore teaching experience $(56.4 \%)$, involving paid $(78.3 \%)$ offshore teaching assignments in Asia (87.6\%).

\subsection{Data Collection Procedures}

Data were collected electronically using commercial web survey software called Survey Monkey, which provides multiple layers of security and confidentiality. The web-based survey was created as a link to be sent in an email message. Preceding the link to the survey, an introductory email letter explaining the nature and purpose of the present study, an informed consent form, and directions for completing the questionnaire were included. The estimated time required to complete the survey was up to 15 minutes. To encourage participation, an electronic message was sent to participants to thank those who had completed the survey and to remind those who had not to please take part. Response rate was $10.6 \%(n=193)$.

\subsection{Statistical Procedures}

\section{a. Exploratory Factor Analysis (EFA)}

Consistent with analytic procedures for the empirical assessment of construct validity (Hair et al. 2006; Netemeyer, Bearden \& Sharma 2003), the first step for validation of the STITAS questionnaire was to refine measurement scales, assess unidimensionality, and examine internal consistency of scales. EFA can be executed in the early stages of scale development to determine the number of latent constructs underlying a set of items (Wegener \& Fabrigar 2000).

For this study, the decision to extract the factors was based on five criteria: item loadings, Kaiser's criterion, scree plot tests, proportion of variance and interpretability of the factors (Costello \& Osborne 2005). Items were eliminated when factor loadings were less than 0.4, and when cross loadings were high or when items loaded on more than one factor (Pallant 2009; Suhr 2006). Kaiser's eigenvalue criterion of values greater than one was used to determine the optimum number of factors that could be extracted. (Suhr 2006). Additionally, Cattell's (1966) scree test and interpretability were considered when determining the appropriate number of factors to retain (Browne 2001). 


\section{b. Confirmatory Factor Analysis (CFA)}

Empirical data reduction techniques such as EFA do not address the issue of content adequacy, which is based on the theoretical correspondence between a measure's items and a factor's delineated content domain (Brown 2006). Further, EFA does not ensure that items loading on a single factor are measuring the same theoretical content (Hancock \& Mueller 2006). Following Schreiber et al. (2006), this study used CFA to improve the rigor with which content validity is measured.

CFA can also help to determine whether data are consistent within constrained structures to meet conditions of model identification (Worthington \& Whittaker 2006; Lance \& Vandenberg 2001). There are three categories of fit indices (i.e., absolute fit, incremental fit, and parsimonious fit indices) through which model fitness assessment can be made (Suhr 2006). Kline (2010) advocated use of the Standardised Root Mean-square Residual (SRMR) to assess model fit. This value represents the standardized difference between covariances in observed data (model) and predicted covariances (in the predicted model). Researchers (Hooper, Coughlan \& Mullen 2008; Schreiber et al. 2006; Hu \& Bentler 1999) deem that SRMR values as high as 0.08 are acceptable. Accordingly, $\chi^{2} / d f \leq 2$ or 3 ; GFI, TLI and CFI of 0.90 or greater; RMSEA and SRMR less than 0.08 were adopted (Kline 2010).

\section{RESULTS}

\subsection{Exploratory Factor Analysis (EFA)}

The EFA of 26 items involving the POS scale resulting in a four-factor structure with loadings equal to .40 or above (Table 3). Factor loading range from .41 to .86. Six items (HR5, HR6, HR7, HR8, COMP5, PROMO3) were deleted because their loadings were less than 0.4 and these items displayed cross loadings. Interpretation of the four-factor solution, which explained $54 \%$ of the variance, was accomplished by relating clusters of items for each construct to their corresponding construct. These four factors are named: perceived organisational support, perceived organisational HR support, perceived organisational financial support, and perceived organisational career support. Discriminant validity is demonstrated as correlations between factors range between $r=.18$ and $r=.34$

\subsection{Confirmatory Factor Analysis (CFA)}

Perceived organisational support comprises four factors (i.e., perceived organisational support, perceived organisational HR support, perceived organisational financial support, perceived organisational career support). Respectively, these factors are made up of five perceived organisation support, three perceived organisational HR support, three perceived organisational financial support, and two perceived organisational career support items. However, following the multi-factor congeneric measurement model (Figure 1), the final perceived organisational support measurement model comprises 13 items that fit the data well: $\chi 2=127.175, \mathrm{df}=71, \chi 2 / \mathrm{df}=1.791, \mathrm{RMSEA}=0.065, \mathrm{SRMR}=0.0533, \mathrm{TLI}=0.925, \mathrm{CFI}=0.942$, $\mathrm{GFI}=0.917$. All $p s<.001$. 


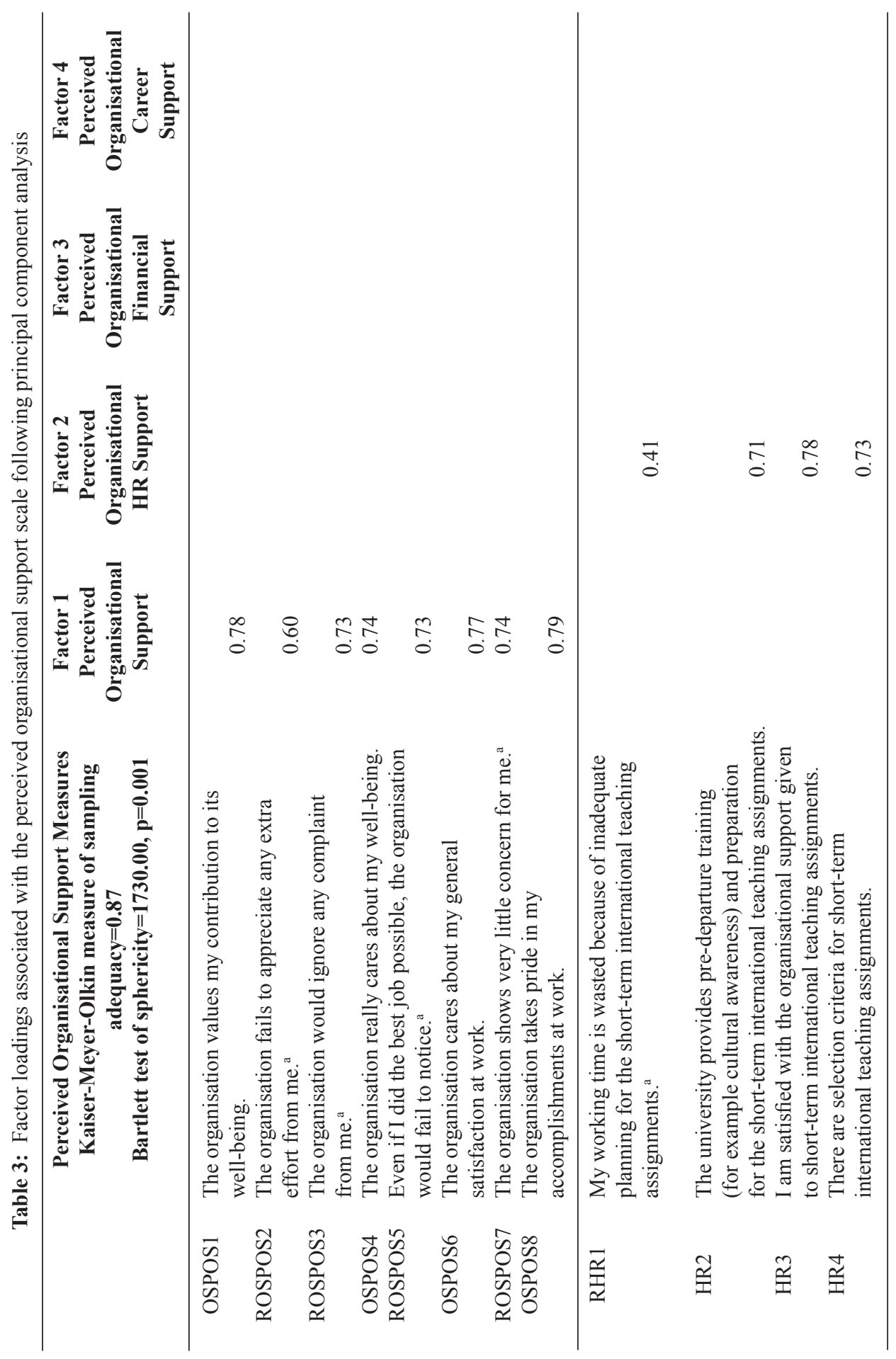




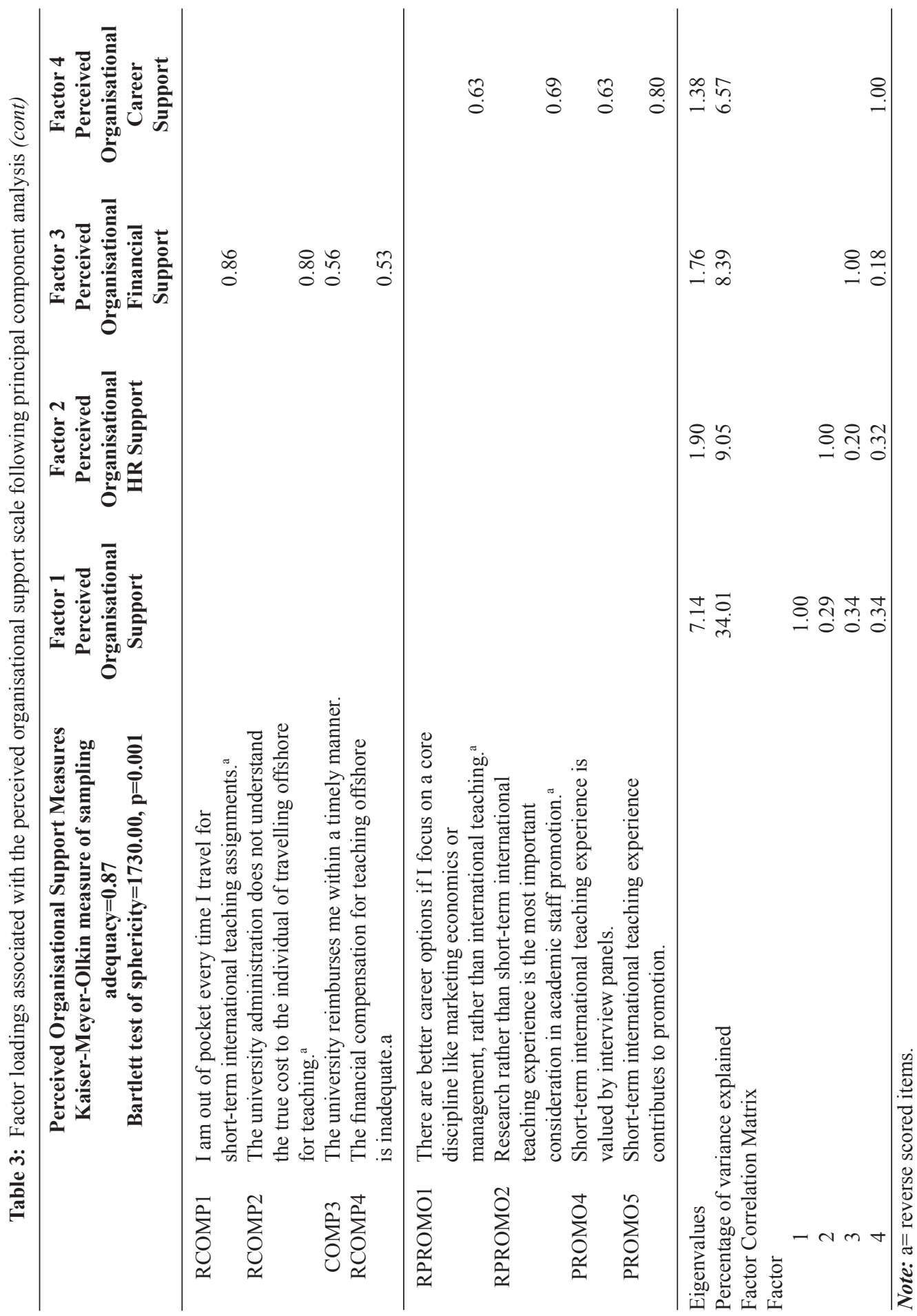


Figure 1: Four-factor perceived organisational support measurement model

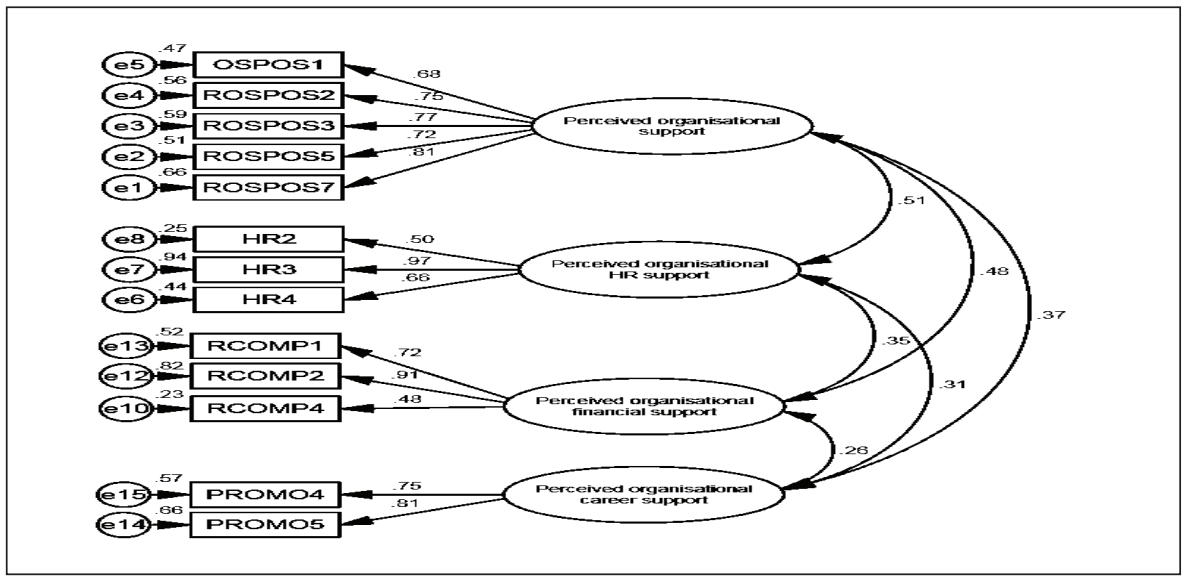

\subsection{Convergent and Discriminant Validity}

Reliability and validity are fundamental cornerstones in the evaluation of research. This study evaluates construct validity in relation to convergent and divergent validity. Convergent validity is agreement between measures of the same construct (Gefen, Straub \& Boudreau 2000), as indicated by factor loadings, variance extracted (VE) (Fornell \& Larcker 1981), construct reliability (CR) (Straub, Boudreau \& Gefen 2004), and associated significant $t$-values (Gallagher, Ting \& Palmer 2008). VE assesses the degree of variance captured by a construct's measure due to random measurement error (Gefen, Straub \& Boudreau 2000). CR is a measure of internal consistency (Kline 2010). According to Gallagher, Ting and Palmer (2008), VE values should be .5 or greater and estimated CR should be above a threshold of .6 to suggest adequate convergent validity. Tables 4 displays standardized factor loadings, $t$-values, CR, and $\mathrm{VE}$ values for the four-factor perceived organisational support measurement model.

\subsection{Reliability}

Finally, Cronbach's alpha was calculated to assess reliability of items loading on factors. Nunnally and Bernstein (1994) recommend that at early stages of research, alpha standards of reliability should exceed .70. Reliability coefficients (Cronbach's alpha) was calculated for STITAS $(\alpha=0.85)$.

\section{DISCUSSION}

This study describes the empirical procedures used to develop and evaluate an instrument designed to assess perceived support in short-term international teaching assignments. This study began with a 26-items draft instrument that was reduced to 20-items using EFA procedures. To investigate concurrent and discriminant validity for the instrument, this study conducted a CFA of a multi-factor model, comprising four subscales. The four subscales were labelled: perceived organisational support, perceived organisational HR support, 
Table 4: Standardized factor loadings, t-values, factor score weights, standardized factor score weights, construct reliability and variance extracted values for the four-factor perceived organisational support measurement model

\begin{tabular}{|c|c|c|c|c|}
\hline Construct & $\begin{array}{c}\text { Standardised } \\
\text { Factor } \\
\text { Loading }\end{array}$ & t-value ${ }^{\mathrm{a}}$ & $\begin{array}{l}\text { Construct } \\
\text { Reliability } \\
\text { (CR) }\end{array}$ & $\begin{array}{c}\text { Variance } \\
\text { Extracted } \\
(\text { VE) }\end{array}$ \\
\hline Perceived Organisational Support & & & 0.86 & 0.56 \\
\hline OSPOS1 & 0.98 & 9.65 & & \\
\hline ROSPOS2 & 0.75 & 10.81 & & \\
\hline ROSPOS3 & 0.77 & 11.15 & & \\
\hline ROSPOS5 & 0.71 & 10.20 & & \\
\hline ROSPOS7 & 0.81 & Scaling & & \\
\hline Perceived Organisational HR Support & & & 0.77 & 0.54 \\
\hline HR2 & 0.50 & 6.39 & & \\
\hline HR3 & 0.97 & 7.84 & & \\
\hline HR4 & 0.66 & Scaling & & \\
\hline Perceived Organisational Financial Support & & & 0.76 & 0.53 \\
\hline RCOMP1 & 0.72 & 6.11 & & \\
\hline RCOMP2 & 0.91 & 5.96 & & \\
\hline RCOMP4 & 0.48 & Scaling & & \\
\hline Perceived Organisational Career Support & & & 0.76 & 0.61 \\
\hline PROMO4 & 0.75 & 4.74 & & \\
\hline PROMO5 & 0.81 & Scaling & & \\
\hline
\end{tabular}

Note: ${ }^{a}$ Scaling denotes standardized factor loadings value of indicator set to 1 to enable latent factor identification.

perceived organisational financial support, and perceived organisational career support. From the reliability and construct validity evidence presented, STITAS is a useful measure of the support construct in short-term international teaching assignments. In line with the benefits if the STITAS for international assignments, this measure could possibly be used to identify the appropriate support for academics involve in offshore teaching.

However, the current findings should be assessed in the light of two principal limitations associated with this research: limited generalizability of finding and measurement. First, the present study involved Australian academics in 24 Australian universities. Australian academics might be quite different from those overseas. Moreover, it is unclear whether there are differences in terms of organisational culture and internationalisation of staff, and whether university status and rankings, structures, and orientation to research are other important factors that need to be considered. Thus, it is possible that Australian academics' experiences differ from those living in other countries. Accordingly, the generalizability of findings to other populations may be limited.

Finally, the attempt to address complexities associated with measures of perceived organisational support poses as yet another limitation. This investigation appears to be the first attempt to empirically validate a multifaceted measure of perceived organisational support for offshore teaching. At the risk of sounding somewhat conservative, the current findings should be considered as preliminary, requiring validation across multiple and differing samples. 


\section{CONCLUSION}

This study culminated in the development of Short-term International Teaching Assignments Scale (STITAS) for $f y$-in, fly-out academics. The scale represents a crucial step in enhancing support to fly-in, fly-out academics, highlighting salient issues in short-term international teaching assignments. Further refinement of the instrument could enrich our understanding and prediction of selected outcomes for academics. Further, the proposed scale provides a blueprint for the development of other related support models that could possibly conceptualize academics' needs and demands associated with overseas teaching assignment.

\section{ACKNOWLEDGEMENT}

Parts of this paper were presented at the Proceedings of Asia Pacific Marketing and Management Conference, 20-22 November, 2013. Sarawak, Malaysia.

\section{REFERENCES}

Adam, S. (2001). Transnational Education Project Report and Recommendations. Paper presented at the Confederation of European Union Rectors' Conferences, University of Westminster.

Ahsan, M., \& Musteen, M. (2011). Multinational enterprises' Entry Mode Strategies and Uncertainty: A Review and Extension. International Journal of Management Reviews, 13(4), 376-392.

Allen, D. G., Shore, L. M., \& Griffeth, R. W. (2003). The Role of Perceived Organizational Support and Supportive Human Resource Practices in the Turnover Process. Journal of Management, 29(1), 99-118.

Armeli, S., Eisenberger, R., Fasolo, P., \& Lynch, P. (1998). Perceived Organizational Support and Police Performance: The Moderating Influence of Socioemotional Needs. Journal of Applied Psychology, 83(2), 288-297.

Aselage, J., \& Eisenberger, R. (2003). Perceived organizational support and psychological contracts: a theoretical integration. Journal of Organizational Behavior, 24, 491-509.

Australia Education International. (2011). End of Year Summary of International Student Enrolment Data1 - Australia - 2011. Australia: Australian Education International.

Australian Bureau of Statistics. (2011). Australian Social Trends: International Students. Australia: Australian Bureau of Statistics.

AVCC (2001). Australian Vice-Chancellors' Committee. Retrieved August 14, 2009, from http://www.universitiesaustralia.edu.au/content.asp?page=/publications/index.htm

Bay, U. (2011). Unpacking neo-liberal technologies of government in Australian highereducation social work departments. Journal of Social Work, 11(2), 222-236.

Blau, P. (1964). Exchange and Power in Social Life. New York, NY: Wiley. 
Bolton, D., \& Nie, R. (2010). Creating Value in Transnational Higher Education: The Role of Stakeholder Management. Academy of Management Learning \& Education, 9(4), 701-714.

Brown, T. A. (2006). Confirmatory Factor Analysis for Applied Research. New York: Guilford Press.

Browne, M. W. (2001). An overview of analytic rotation in exploratory factor analysis. Multivariate Behavioral Research, 36(1), 111-150.

Cattell, R. B. (1966). The scree test for the number of factors. Multivariate Behavioral Research, 1(2), 245-276.

Cerny, P. G. (2004). Mapping varieties of neo-liberalism. IPEG Papers in Global Political Economy No. 12.

Colquitt, J. A., Scott, B. A., \& LePine, J. A. (2007). Trust, trustworthiness, and trust propensity: A meta-analytic test of their unique relationships with risk taking and job performance. Journal of Applied Psychology, 92(4), 909-927.

Costello, A. B., \& Osborne, J. W. (2005). Best Practices in Exploratory Factor Analysis: Four Recommendations for Getting the Most From Your Analysis. Practical Assessment Research \& Evaluation, 10(7), 1-9.

Coyle-Shapiro, J. A-M., \& Conway, N. (2005). Exchange relationships : examining psychological contracts and perceived organizational support. Journal of Applied Psychology, 90(4), 774-781.

Creswell, J. (2007). Qualitative Inquiry and research design: Choosing among five traditions. Thousand Oaks, CA: Sage Publications, Inc.

Debowski, S. (2003). Lost in internationalised space: The challenge of academics teaching offshore. Paper presented at the IDP Conference 'Securing the Future for International Education: Managing Growth and Diversity, Melbourne.

DEEWR (2011). Student 2010 Full Year: Selected Higher Education Statistics. Australia: Department of Education, Employment and Workplace Relations.

DEST (2011). Statistics relating to higher education. Australia: Department of Education, Science, and Training.

Dunn, L., \& Wallace, M. (2006). Australian academic and transnational teaching: an exploratory study of their preparedness and experiences. Higher Education Research and Development, 25(4), 357-369.

Edwards, M. R., (2009). HR, perceived organisational support and organisational identification: An analysis after organisational formation. Human Resource Management Journal, 19(1), 91-116.

Eisenberger, R., Huntington, R., Hutchison, S., \& Sowa, D. (1986). Perceived organizational support. Journal of Applied Psychology, 71(3), 500-507. 
Eisenberger, R., Stinglhamber, F., Vandenberghe, C., Sucharski, IL., \& Rhoades, L. (2002). Perceived Supervisor Support: Contributions to Perceived Organizational Support and Employee Retention. Journal of Applied Psychology, 87(3), 565-573.

Erdogan, B., \& Enders, J. (2007). Support from the top: Supervisors' perceived organizational support as a moderator of leader-member exchange to satisfaction and performance relationships. Journal of Applied Psychology, 92(2), 321-330.

Fornell, C., \& Larcker, D. (1981). Evaluating structural equation models with unobservable variables and measurement error. Journal Marketing Research, 18(1), 39-50.

Gallagher, D., Ting, L., \& Palmer, A. (2008). A journey into the unknown; taking the fear out of structural equation modeling with AMOS for the first-time user. The Marketing Review, 8(3), 255-275.

Gefen, D., Straub, D. W., \& Boudreau, M. (2000). Structural Equation Modeling Techniques and Regression: Guidelines For Research Practice. Communications of AIS, 4(7), 2-79.

Gouldner, A. W. (1960). The norm of reciprocity: A preliminary statement. American Sociological Review, 25(2), 161-178.

Gribble, K., \& Ziguras, C. (2003). Learning to teach offshore: pre-departure training for lecturers in transnational programs. Higher Education Research and Development, 22(2), 206-216.

Hair, J., Black, W., Babin, B., Anderson, R., \& Tatham, R. (2006). Multivariate Data Analysis, $6^{\text {th }}$ edn. Upper Saddle River, New Jersey: Pearson Prentice Hall.

Hancock, G. R., \& Mueller, R. O. (2006) Structural Equation Modeling: A Second Course. Greenwich, CT: Information Age.

Hoffman, D. M. (2009). Changing Academic Mobility Patterns and International Migration: What Will Academic Mobility Mean in the $21^{\text {st }}$ Century? Journal of Studies in International Education, 13(3), 347-364.

Hooper, D., Coughlan, J., \& Mullen, M. R. (2008) Structural Equation Modelling: Guidelines for Determining Model Fit. The Electronic Journal of Business Research Methods, 6(1), $53-60$.

Hu, L., \& Bentler, P. M. (1999). Cutoff criteria for fit indexes in covariance structure analysis: Conventional criteria versus new alternatives. Structural Equation Modeling, 6(1), 1-55.

IDP. (2009). Retrieved August 13, 2009, from http://www.idp.com/research/statistics/ international_education_stats.aspx

IDP. (2010). Global Student Mobility: An Australian Perspective Five Years On. Sydney, Australia: IDP Education Pty Ltd.

Jais, J. (2012). Flying Academics - Examining Short-Term International Teaching Assignments Impact on Academics' Career Success and Work-Life Balance. Doctoral Dissertation, RMIT University. 
Kim, T. (2009a). Shifting patterns of transnational academic mobility: a comparative and historical approach. Comparative Education, 45(3), 387 - 403.

Kim, T. (2009b). Transnational Academic Mobility, Internationalization and Interculturality in Higher Education. Intercultural Education, 20(5), 395-405.

Kline, R. B. (2010). Principles and Practice of Structural Equation Modeling $3^{\text {rd }}$ edn. New York: The Guilford Press.0

Kraimer, M. L., \& Wayne, S. J. (2004). An Examination of Perceived Organizational Support as a Multidimensional Construct in the Context of an Expatriate Assignment. Journal of Management, 30(2), 209-237.

Lance, C. E., \& Vandenberg, R. J. (2001). Confirmatory factor analysis. In F. Drasgow \& N. Schmitt (Eds), Measuring and analyzing behavior in organizations: Advances in measurement and data analysis (pp. 221-256). San Francisco: Jossey-Bass.

Leask, B. (2004). Transnational Education and Intercultural Learning: Reconstructing the Offshore Teaching Team to Enhance Internationalisation. Paper presented at the Australian Universities Quality Forum Adelaide, Australia.

Marginson, S. (1999). After globalization: emerging politics of education. Journal of Educational Administration Policy, 14(1), 19-31.

Marginson, S. (2003). Markets in higher education: national and global competition. Paper presented at the ANZARE/AARE Joint Conference, Auckland, New Zealand.

Marginson, S., \& Considine, M. (2000a). The Enterprise University: Power, Governance and Re-invention in Australia. Sydney: Cambridge University Press.

Marginson, S., \& Considine, M. (2000b). The enterprise university: power, governance and reinvention in Australia. Melbourne: Cambridge University Press.

McBurnie, G., \& Ziguras, C. (2001). The regulation of transnational higher education in Southeast Asia: Case studies of Hong Kong, Malaysia and Australia. Higher Education, 42(1), 85-105.

Meek, V. L., \& Hayden, M. (2005). The governance of public universities in Australia: Trends and contemporary issues. In F. Iacobucci \& C. Tuohy (Eds), Taking public universities seriously (pp. 379-401). Toronto: University of Toronto Press.

Naidoo, V. (2006). International education. Journal of Research in International Education, $5(3), 323-345$.

Naidoo, V. (2009). Transnational Higher Education: A Stock Take of Current Activity. Journal of Studies in International Education, 13(3), 310-330.

Netemeyer, R. G., Bearden, W. O., \& Sharma, S. (2003). Scaling Procedures: Issues and Applications. Thousand Oaks, California: SAGE Publications.

Nunnally, J. C., \& Bernstein, I. H. (1994). Psychometric theory 3rd edn. New York: McGrawHill. 
Onsman, A. (2010). Cross-border teaching and the globalization of higher education. USA: The Edwin Mellen Press Ltd.

Pallant, J. (2009). SPSS: Survival Manual: a step by step guide to data analysis using SPSS, 3rd edn. Australia: Allen \& Unwin.

Rhoades, L., \& Eisenberger, R. (2002). Perceived organizational support: A review of the literature. Journal of Applied Psychology, 87(4), 698-714.

Schreiber, J. B., Nora, A., Stage, F. K., \& King, J. (2006). Reporting Structural Equation Modeling and Confirmatory Factor Analysis Results: A Review. The Journal of Educational Research, 99(6), 323-338.

Shore, L. M., \& Tetrick, L. E. (1991). A construct validity study of the survey of perceived organizational support. Journal of Applied Psychology, 76(5), 637-643.

Straub, D., Boudreau, M. C., \& Gefen, D. (2004). Validation guidelines for IS positivist research. Communications of AIS, 13(24), 380-427.

Suhr, D. D. (2006). Exploratory or Confirmatory Factor Analysis? Paper presented at the SAS Users Group International Conference (SUGI31), San Francisco, CA.

Wegener, D. T., \& Fabrigar, L. R. (2000). Analysis and design for nonexperimental data: Addressing causal and noncausal hypotheses. In H. T. Reis \& C. M. Judd (Eds), Handbook of research methods in social and personality psychology (pp. 412-450). New York: Cambridge University Press.

Worthington, R. L., \& Whittaker, T. A. (2006). Scale Development Research: A Content Analysis and Whittaker Recommendations for Best Practices. The Counseling Psychologist, 34(6), 806-838.

Zheng, J. (2010). Neoliberal Globalization, Higher Education Policies and International Student Flows: An Exploratory Case Study of Chinese Graduate Student Flows to Canada. Journal of Alternative Perspectives in the Social Sciences, 2(1), 216-244.

Ziguras, C. (2007). Good Practice in Transnational Education A Guide for New Zealand Providers. Wellington: Education New Zealand Trust.

Ziguras, C., \& McBurnie, G. (2008). The impact of trade liberalization on transnational education. In L. Dunn \& M. Wallace (Eds), Transnational Education: Issues and trends in offshore higher education (pp. 3-13). Oxon: Routledge, Milton Park. 